\title{
CENTRO DE ESTUDOS DAS NORMAS INTERNACIONAIS DO TRABALHO
}

\author{
Histórico
}

O Centro de Estudos das Normas Internacionais do Trabalho, CENOIT, nasceu de uma proposta dos alunos do $5^{\circ}$ ano da Faculdade da Turma de 1994, formulada ao doutor Cássio de Mesquita Barros Júnior, professor titular de Direito do Trabalho, após as aulas de Direito Internacional do Trabalho. Sabendo ser o professor membro da Comissão de Peritos da Organização Internacional do Trabalho OIT os alunos mostraram-se vivamente interessados em descobrir uma forma de continuarem seus estudos sobre as normas internacionais do trabalho, contidas nas Convenções e Recomendações aprovadas pela Conferência Internacional do Trabalho que se realiza todos os anos no mês de junho, em Genebra. Desejavam ter a possibilidade de conhecer melhor a OIT, hoje o grande "forum" em que se debatem as questões sociais. Queriam saber mais sobre os objetivos e programas da Organização Internacional do Trabalho, conteúdo das normas e jurisprudência da Comissão de Peritos na interpretação e aplicação das normas constantes das Convenções. Identificar claramente as obrigações dos 178 Estados-membros, dos empregadores e dos trabalhadores, tudo particularmente importante na era da globalização.

O professor teve, então, a idéia de organizar o "Centro de Estudos" organismo previsto nos programas da Universidade de São Paulo, e que já constituídos em outras áreas da Universidade atuam com êxito. Graças ao dedicado apoio do professor Álvaro Villaça Azevedo, o Centro, constituído juridicamente, foi solenemente instalado no dia $1^{\circ}$ de outubro de 1997, em sessão realizada na Sala da Congregação, presidida pelo mesmo professor, com a presença do diretor de Normas da OIT, doutor Hector Bartolomei de La Cruz, membro honorário do Centro, e de vários professores e autoridades.

Na sessão solene de instalação, o diretor de Normas da OIT anunciou a remessa ao Centro de uma bibliografia básica e a instalação de uma Antena para Conexão direta com Genebra. Os aparatos cedidos, gratuitamente, permitem a obtenção pronta de documentos e textos da Organização diretamente de Genebra. O I Seminário sobre normas já foi marcado para os dias 03 e 04 de agosto do corrente ano de 1998, no Auditório XI de Agosto, localizado no prédio anexo da Faculdade 
de Direito da Universidade de São Paulo e se destina a preparar os alunos e a comunidade interessada, no manuseio dos programas informatizados, notadamente, sistema ILOLEX e NATLEX.

A ata de instalação e os estatutos do Centro permitem uma visão concreta de sua estrutura jurídica e da gama de atividades que pode empreender.

Com a presença do senhor Hector Bartolomei de La Cruz, diretor de Normas da Organização Internacional do Trabalho-OIT, do professor Jean Michel Servais, da OIT de Genebra, professores das Faculdades de Direito de BolognaItália, Paris, Londres, Louven, na Bélgica, França, Buenos Aires, Montevidéu, Madrid, do Instituto Max Planck, da Alemanha, do doutor João Carlos Alexim, diretor da OIT no Brasil, do professor Antonio Augusto Junho Anastasia, secretário geral do Ministério do Trabalho, do doutor Walter Barelli, secretário do Emprego e Relação do Trabalho do Estado de São Paulo, e de autoridades, magistrados e professores de Direito do Trabalho e Direito Internacional desta Faculdade, ter-se-á a sessão solene de instalação do Centro de Estudos de Normas Internacionais do Trabalho - entidade formada por iniciativa dos alunos desta Universidade, sob a direção do professor Cássio de Mesquita Barros Júnior.

\section{Solenidade de inauguração}

A instalação solene da entidade foi aprazada para o dia $1^{\circ}$ de outubro de 1997, em razão da presença desta autoridade da Organização Internacional do Trabalho - OIT, no País.

O local da inauguração foi a Sala da Congregação da Faculdade de Direito, uma vez que o novo Centro congrega pequeno grupo inicial selecionado, e cerca de trinta membros entre acadêmicos, pós-graduandos e bacharéis em Direito do Trabalho.

A cerimônia foi presidida pelo Diretor da Faculdade de Direito, professor Álvaro Villaça Azevedo.

\section{Ata da posse solene da Diretoria}

Ao dia primeiro de outubro de mil novecentos e noventa e sete, na Sala da Congregação da Faculdade de Direito da Universidade de São Paulo, sob a direção do Diretor da Faculdade de Direito, professor Álvaro Villaça Azevedo e com 
a presença do professor Antonio Augusto Junho Anastasia, doutor Hector Bartolomei de La Cruz, doutor Jefferson Luiz Pereira Coelho e dos professores e autoridades que assinam o livro de presença, foi solenemente empossada a Diretoria do Centro de Estudos das Normas Internacionais do Trabalho-CENOIT, assim constituída: diretor-presidente, professor doutor Cássio de Mesquita Barros Júnior, diretora-secretária doutora Maria Thereza Vargas Escobar Ferraz de Camargo e diretor-tesoureiro, doutor Mariano Gaspar. Foram também empossados os membros do Conselho, assim constituído: presidente: professor doutor Cássio de Mesquita Barros Júnior, diretor vice-presidente: doutor Roberto Covolo Bórtoli e conselheiros: doutora Valéria Nicolau Sanchez, doutor Elio Antonio Colombo Júnior, doutor Alcides de Souza Pinto, doutor Roberto Bedrikow, doutora Ana Paula Paiva Mesquita Barros Cavenaghi, doutor Cassius Marcellus Zomignani, doutora Regina A. Duarte Torres de Carvalho e doutora Ulrike Frieda Hedwig Beiderwellen Bedrikow. Usaram da palavra o professor doutor Álvaro Villaça Azevedo, o professor doutor Cássio de Mesquita Barros Júnior, presidente honorário, doutor Hector Bartolomei de La Cruz, professor Antonio Augusto Junho Anastasia e o doutor Jefferson Luiz Pereira Coelho. 



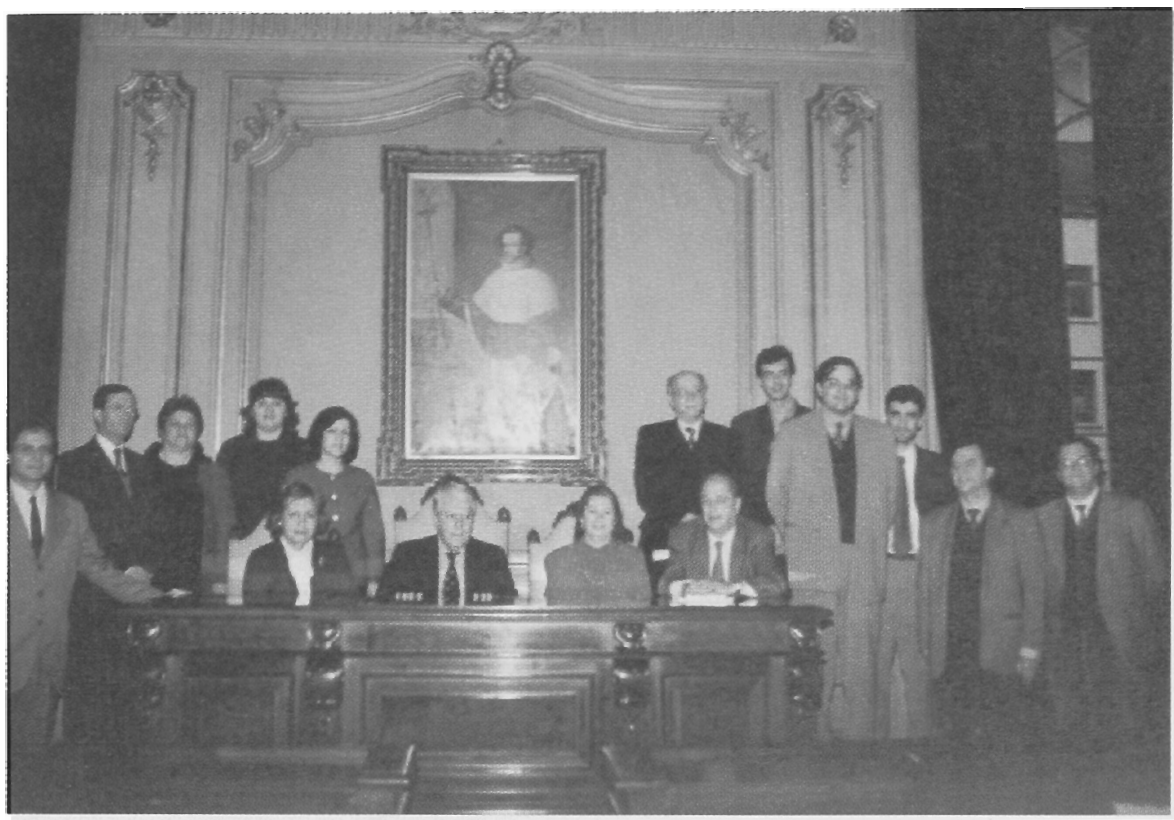

Solenidade de inauguração do Centro de Estudos das Nornas Internacionais do Trabalho 